\title{
KEUNGGULAN BERSAING UKM YANG DIPENGARUHI OLEH ORIENTASI PASAR DAN INOVASI PRODUK
}

Oleh:

\author{
Taufik Alwi'); Esti Handayani') \\ Sekolah Tinggi Ilmu Ekonomi IPWI Jakarta1,2) \\ alwitaufik@yahoo.com ${ }^{1)}$; esti.aulia@yahoo.co.id²)
}

\begin{abstract}
ABSTRAK
Keberlangsungan bisnis di sektor UKM tidak terlepas dari strategi yang berorientasi pasar dan inovasi produk guna meraih keunggulan bersaing. Penelitian ini bertujuan untuk mengetahui pengaruh orientasi pasar dan inovasi produk terhadap keunggulan bersaing. Metode penelitian yang digunakan adalah survei, melibatkan 35 orang sampel penelitian secara purposive non random sampling yang difokuskan pada restoran/kafe yang mengusung tagline cita rasa mancanegara di Jalan Margonda Raya Kota Depok. Alat analisis yang digunakan berupa uji asumsi klasik, uji validitas dan reliabilitas, uji korelasi parsial dan berganda, uji regresi, uji t dan uji ANOVA.

Penelitian menemukan bahwa orientasi pasar dan inovasi produk berkontribusi pengaruh terhadap keunggulan bersaing sebesar 85,3\%. Model persamaan regresi linear berganda, $Y=13,702+$ 0,542 X1 + 0,314 X2. Berdasarkan uji hipotesis disimpulkan bahwa variabel orientasi pasar perpengaruh positif terhadap keunggulan bersaing, demikian pula variabel inovasi produk berpengaruh positif terhadap keunggulan bersaing. Bagi pelaku bisnis UKM sangat perlu untuk memberikan atensi dalam mendesain strategi peningkatan keunggulan bersaing melalui penekanan pada strategi yang berorientasi pasar dan inovasi produk.
\end{abstract}

Kata kunci:

Orientasi pasar, inovasi produk, keunggulan bersaing, UKM

\section{PENDAHULUAN}

Keunggulan bersaing (competitive advantages) dalam sektor usaha kecil dan menengah (UKM) akan menentukan keberlangsungan bisnis. Dalam turbulensi persaingan bisnis yang tinggi, dituntut setiap pebisnis untuk menghadirkan keunggulan bersaing, diantaranya melalui strategi inovasi produk (Han et al,1998) dan orientasi pasar (Narver and Slater, 1995). Orientasi produk akan memperluas pasar (Porter, 2008) sehingga orientasi produk telah menjadi bagian strategi penting dalam aktivitas bisnis masa depan (Andrew et al, 2010).

Kesadaran terhadap esensi orientasi pasar (market orientation) idealnya dilakukan secara berkesinambungan sebagai upaya reorientasi pasar yang mendasari strategi bisnis. UKM jenis bisnis kuliner pada beberapa kasus dinilai kuat dan tahan krisis karena menunjang kebutuhan dasar manusia, yaitu kebutuhan makan dan 
minum. Jalan Margonda Raya Depok Jawa Barat salah satunya dikenal dengan banyaknya UKM yang bergerak di bisnis kuliner berupa restoran, cafe, dan warung makan. dengan beragam brand, baik lokal sampai internasional. Pada tahapan observasi awal ditemukan beberapa fenomena seperti munculnya pebisnis kuliner yang baru, masih eksisnya pebisnis lama, tutup/hilangnya pebisnis lama atau pun berubahnya format dari bisnis yang pernah ada. Di kawasan Jalan Margonda terdapat restoran franchise internasional maupun lokal, berbentuk cabang atau pun restoran/cafe dengan entitas yang mandiri. Lokasi masing-masing pebisnis kuliner ada yang bisa langsung diakses di pinggir jalan maupun di dalam mall/pusat perbelanjaan. Puluhan restoran/kafe di sepanjang Jalan Margonda dapat dilihat pada tabel berikut ini.

\section{Tabel 1}

Restoran dan Kafe di Margonda Raya Depok

\begin{tabular}{|l|l|}
\hline Lokasi Pinggir Jalan (Akses langsung) & \multicolumn{1}{|c|}{ Lokasi di dalam Mall/Pusat Perbelanjaan } \\
\hline Restoran Sederhana, KFC, The Harvest Cakes, & Starbucks Coffee, CFC, A\&W, Mc Donald's, \\
Café Hello Bingsu, Roti Bakar Eddy, Sea Food & Hoka-Hoka Bento, KFC, Burger King, J.Co \\
Perang Kerang, Ayam Bakar Christina, Sop & Donuts \& Coffee, Breadtalk, Hanamasa, Ojju, \\
Durian Margonda, Pecel Lele Lela, Daebak Fan & Yoshinoya, Maxx Coffee, Imperial Kitchen \& \\
Cafe, Kedai Susu dan Ketan, Istana Martabak, & Dimsum, Steak Moen-Moen, Sushi Tei, \\
Delysh Coffee Shop, Pancong Lava, Mang & Mujigae, Ta Wan, Mujigae, Shirokuma, Imperial \\
Kabayan, Sushi Miyabi, Warung Spesial Sambal, & Kitchen \& Dimsum, Marugame Udon, Thay \\
Kimung Kedai Kopi, Pidie 2000, Healthy Beans & Aley, Sagoo Kitchen, Wingstop, Hokkaido \\
Kembang Tahu,Yellow Truck Coffee, Warung & Baked Cheese Tart, Hong Tang, Dum Dum Thai \\
Pasta, Kami Ruang \& Caffee, Pizza Hut \& PHD, & Drinks, Nanny's Pavillon, Lotteria, Chatime, \\
Panties Pizza, Es Pocong, Bakso Boedjangan, & Puyo Silly Desserts, Kopka, Holland Bakery, \\
Kopibar, Warung Upnormal, Makaroni Ngehe, & Tong Tji Tea Bar, Mister Baso, KFC, Iraezlank \\
Baperin Aja, Takarajima, Abuba Steak, Richeese & Kitchen, Teh Cup Poci, D' Cost, Cheese \\
Factory, Hello Bingsu Cafe, Zoe Cafe \& Library, & Chicken, Steak Moen-Moen, Kantin An-Nida, \\
Mix Dinner \& Florist, Fat Bubble, Milan Pizzeria & Solo Asia, Ranah Minang, Raa Cha, Gokana \\
Cafe, Shirin Arabian Restaurant, Holland Bakery, & Ramen \& Teppan, Warung Tekko, \\
Nasi Pecel Mbak Ira, & \\
\hline
\end{tabular}

Sumber: Data Penelitian diolah

Perusahaan berorientasi pasar (market orientation) salah satunya adalah atensi terhadap pelanggan dengan menanggapi kebutuhan (needs) dan keinginan (wants) konsumen dan berusaha untuk memuaskan pelanggan mereka dan menciptakan nilai pelanggan disamping juga memperhatikan dinamika kompetisi bisnis. Keunikan hasil inovasi produk (product innovation) berkontribusi dan menjadi penentu pada keunggulan bersaing ((McDaniel, 2002, Urbancova, 2013). Ketika pelanggan memperoleh perbedaan yang unik, unggul dan konsisten dalam atribut yang penting dari produk yang dihasilkan dibandingkan dengan pesaing, maka keunggulan bersaing akan dapat diraih. Hal ini menunjukkan pula pentingnya pelaku bisnis untuk senantiasa memperhatikan realitas dan dinamika pasar.

Kehadiran UKM dalam bisnis restoran/kafe lokal dengan cita rasa mancanegara telah menghadirkan beragam pilihan bagi konsumen dan berkonsekuensi logis pada kompetisi yang semakin meningkat. Tantangan mengelola bisnis berbasis orientasi pasar dan kepedulian pada inovasi produk dinilai esensial dalam menciptakan keunggulan bersaing, baik berhadapan dengan pebisnis franchise brand internasional, franchise nasional/daerah, maupun dengan sesama entitas pebisnis lokal.

\section{TUJUAN PENELITIAN}

Penelitian ini bertujuan untuk mengetahui dan menganalisis pengaruh Orientasi Pasar dan Inovasi Produk terhadap Keunggulan Bersaing UKM pada sektor bisnis kuliner.

\section{TELAAH LITERATUR DAN PENGEMBANGAN HIPOTESIS Orientasi Pasar (Market Orientation)}

Orientasi pasar mengacu pada keterlibatan seluruh bagian dari perusahaan, bersifat lintas fungsional, aktivitas intelijen informasi pasar, mengidentifikasi kebutuhan para pelaku pasar terutama konsumen, pemasok (supplier) dan pesaing (competitor). Upaya mempelajari cara merespons perubahan 
secara efektif serta menciptakan produk dan layanan yang bernilai akan memberikan keunggulan kompetitif (Kohli dan Jaworski, 1990). Selanjutnya Gar et. al (2006), mengemukakan beberapa aspek nilai dari perusahaan yang berorientasi pasar yaitu: kebijakan berbasis trend pasar, kerja tim dan berkolaborasi (collaboration) berorientasi pasar, adanya empati, penghargaan, pemenuhan janji (keep promises), keterbukaan (openness), kepercayaan (trust).

Orientasi pasar merupakan konsep yang menekankan perhatian pada pasar (market) agar memiliki kemampuan untuk menghadirkan produk (barang dan layanan) yang unggul kepada konsumen. Orientasi pelanggan didefinisikan sebagai suatu proses dimana perusahaan berusaha untuk memenuhi permintaan, nilai, kemampuan, preferensi dan perilaku pelanggan untuk memuaskan kebutuhan konsumen secara dinamis dan berkelanjutan. Pada perspektif ini orientasi pasar meliputi 3 komponen perilaku yaitu orientasi pelanggan, orientasi pesaing dan koordinasi interfungsional (Narver dan Slater, 1990). Pada sisi yang lain, terdapat tiga perspektif yang berbeda mengenai orientasi pasar yaitu dari perspektif budaya (cultural), perilaku (behavioral) dan kinerja (performance) (Homburg \& Pflesser, 2000, Meehan, 1996).

Orientasi pasar berusaha untuk memahami dan memanfaatkan faktor eksternal dari perusahaan guna mengidentifikasi dan menanggapi kebutuhan, permintaan dan ekspektasi pelanggan serta menyediakan produk (barang dan layanan) yang sesuai. Hal tersebut menempatkan orientasi pasar sebagai aspek utama dalam mengembangkan keunggulan kompetitif secara berkelanjutan (sustainable competitive advantage). Orientasi pasar memiliki efek positif pada kinerja bisnis baik dalam jangka pendek maupun jangka panjang (Kumar et al, 2011). Orientasi pasar dalam suatu organisasi mengarah pada perbaikan dalam penjualan dan pertumbuhan profitabilitas, pangsa pasar, kesuksesan produk baru, kepuasan pelanggan, bila dibandingkan dengan perusahaan lain yang tidak peduli dengan esensi berorientasi pasar.

\section{Inovasi Produk (Product Innovation)}

Inovasi produk merupakan salah satu tipe inovasi, selain inovasi proses, inovasi organisasi dan inovasi bisnis. Inovasi produk didefinisikan sebagai produk (barang atau atau jasa) baru yang diperkenalkan ke pasar untuk memenuhi kebutuhan pasar (Damanpour, 1991). Terdapat 3 karakteristik inovasi produk yaitu keunggulan produk, biaya produk dan kredibilitas produk. Inovasi produk adalah inovasi yang digunakan dalam keseluruhan operasi perusahaan dimana sebuah produk baru diciptakan dan dipasarkan, termasuk inovasi di segala proses fungsionil/ kegunaannya (Crawford dan De Benedetto: 2000).

\section{Keunggulan Bersaing (Competitive Advantages)}

Ketika suatu entitas bisnis mampu menawarkan nilai lebih atau keunggulan pada konsumen dibandingkan pesaing maka akan menghasilkan keunggulan bersaing (Kotler et al., 2005, Porter, 2008). Keunggulan bersaing diraih pada aktivitas dalam suatu industri atau pasar melalui penciptaan nilai ekonomi secara kompetitif (Barney, 2010).

\section{Pengembangan Hipotesis}

Penelitian Talaja, et al., (2017) menemukan bahwa orientasi pasar berpengaruh positif secara signifikan terhadap keunggulan bersaing. Demikian pula dengan penelitian oleh Dalimunthe 
(2017) menjelaskan bahwa terdapat pengaruh langsung dan positif secara signifikan antara orientasi pasar terhadap keunggulan bersaing. Didasari hasil penelitian terdahulu, maka hipotesis pertama yang diajukan adalah:

H1 : Orientasi pasar berpengaruh positif terhadap Keunggulan Bersaing

\section{Penelitian Sherlin}

menyimpulkan tidak adanya pengaruh yang signifikan antara inovasi produk terhadap keunggulan bersaing. Hal tersebut berbeda dengan hasil penelitian Djodjobo dan Tawas (2014) yang menyimpulkan bahwa inovasi produk berpengaruh positif dan signifikan terhadap keunggulan bersaing. Demikian pula dengan penelitian Dalimunthe (2017) juga menyimpulkan bahwa terdapat pengaruh langsung dan positif secara signifikan antara inovasi produk terhadap keunggulan bersaing, Peneliti Chen dan Chang (2013) yang secara khusus meneliti inovasi produk berbasis green product inovation juga telah menemukan adanya pengaruh positif dan signifikan inovasi produk terhadap keunggulan bersaing perusahaan. Didasari beberapa hasil penelitian terdahulu tersebut, maka hipotesis kedua yang diajukan adalah sebagai berikut:

H2: Inovasi produk berpengaruh terhadap Keunggulan Bersaing.

Gambar 1

Rerangka Pemikiran

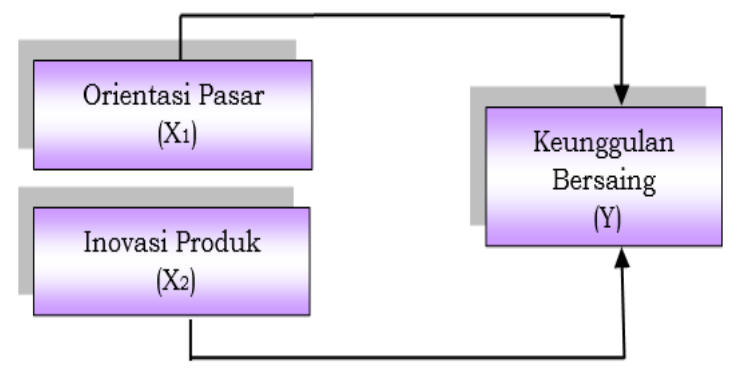

\section{METODE PENELITIAN}

Metode Penelitian

Mengacu pada pendapat Sekaran (2013) maka jenis penelitian ini termasuk pada metode survey. Pendekatan yang digunakan adalah eksplanatory research.

\section{Lokasi dan Waktu Penelitian}

Atas dasar pertimbangan tujuan penelitian, objek penelitian, aksebilitas pengumpulan data, faktor efisiensi waktu dan biaya, maka penelitian dilakukan pada UKM kuliner lokal dengan tagline cita rasa mancanegara yang berada di Jalan Margonda Raya Kota Depok Jawa Barat yang difokuskan di 7 lokasi yaitu: Takarajima, Hello Bingsu Cafe, Shirin Arabian Restaurant, Zoe Cafe \& Library, Mix Dinner \& Florist, Fat Bubble, dan Milan Pizzeria Cafe. Penelitian dilakukan pada Mei s/d Agustus 2017.

\section{Populasi, Teknik Sampling dan Sampel Penelitian}

Populasi terdiri pengusaha UKM Kuliner di Jalan Margonda Raya Depok. Adapun batasan populasi dari restoran/kafe yang memenuhi batasan kriteria sebagai berikut: (1) Bisnis kuliner berbentuk retoran/kafe, (2) Restoran/kafe non Franchise (3) Restoran/kafe lokal yang menggunakan tagline cita rasa mancanegara dan (4) berlokasi akses langsung di pinggir jalan Margonda Raya (5) tidak berada dalam gedung mall/pusat perbelanjaan. Berdasarkan batasan anggota populasi tersebut, anggota populasi dipilih 7 restoran/kafe.

Adapun jumlah sampelnya, dari masing-masing restoran/café, responden dipilih dengan teknik purposed non random sampling, yaitu pemilihan sampel berdasarkan kriteria tertentu yang ditetapkan peneliti (Kuncoro, 2003) dimana: responden, subjek atau elemen yang dipilih ditentukan peneliti dan 
mengabaikan yang tidak sesuai kriteria yang ditentukan (Morissan, 2014).

Peneliti menentukan calon responden yang dilibatkan adalah yang minimal telah lebih dari 2 kali kunjungan. Masingmasing lokasi ditentukan sejumlah 5 responden, sehingga total responden menjadi 35 orang. Jumlah ini memenuhi syarat minimal sampel survey sejumlah minimal 10 kali dari jumlah variabel penelitian (Sekaran, 2013).

\section{Operasionalisasi Variabel}

Tabel 2

Operasionalisasi Variabel Penelitian

\begin{tabular}{|c|c|c|}
\hline Variabel & Indikator & Skala \\
\hline $\begin{array}{l}\text { Orientasi Pasar adalah upaya } \\
\text { mempelajari cara merespon } \\
\text { perubahan kebutuhan dan } \\
\text { pemuasan pelanggan secara efektif } \\
\text { serta menciptakan produk dan } \\
\text { layanan yang akan memberikan } \\
\text { keunggulan kompetitif (Wedel \& } \\
\text { Kamakura, 2002) }\end{array}$ & $\begin{array}{l}\text { - Value utama } \\
\text { - Segmentasi Pasar } \\
\text { - Pemenuhan } \\
\text { Kebutuhan, keinginan } \\
\text { pelanggan } \\
\text { - Orientasi pelanggan } \\
\text { dan pesaing } \\
\text { - Koordinasi lintas fungsi }\end{array}$ & $\begin{array}{c}5 \\
\text { Skala } \\
\text { Likert }\end{array}$ \\
\hline $\begin{array}{l}\text { Inovasi Produk adalah inovasi yang } \\
\text { digunakan dalam keseluruhan } \\
\text { operasi perusahaan dimana sebuah } \\
\text { produk baru diciptakan dan } \\
\text { dipasarkan (Crawford dan De } \\
\text { Benedetto: 2000). }\end{array}$ & $\begin{array}{l}\text { - Desain kekhasan } \\
\text { merek } \\
\text { - Kekhasan produk } \\
\text { - Mengelola Produk } \\
\text { - Keanekaragaman } \\
\text { produk }\end{array}$ & $\begin{array}{c}5 \\
\text { Skala } \\
\text { Likert }\end{array}$ \\
\hline $\begin{array}{l}\text { Keunggulan Bersaing merupakan } \\
\text { sebuah sistem yang unik dan } \\
\text { unggul dibandingkan dengan } \\
\text { pesaing yang bertujuan untuk } \\
\text { memberikan nilai yang baik bagi } \\
\text { konsumen (Barney \& Hesterly, } \\
\text { 2008, Kotler et al., 2005, Porter, } \\
\text { 2008) }\end{array}$ & $\begin{array}{l}\text { - keunikan produk } \\
\text { (sesuai selera) } \\
\text { - kualitas produk, } \\
\text { - kualitas desain produk } \\
\text { - harga bersaing }\end{array}$ & $\begin{array}{c}5 \\
\text { Skala } \\
\text { Likert }\end{array}$ \\
\hline
\end{tabular}

\section{Sumber dan Jenis Data}

Data bersumber dari data primer dan sekunder. Data Primer merupakan data yang diperoleh dari responden secara langsung melalui kuesioner sedangkan Data Sekunder diperoleh dari berbagai referensi yang terkait dengan permasalahan yang diteliti. Jenis data utama penelitian ini berupa data kuantitatif.

\section{Prosedur Pengumpulan Data}

Digunakan dua macam pendekatan yaitu: (1). Metode riset kepustakaan, dilakukan dengan studi telaah literatur, referensi dan jurnal ilmiah yang berhubungan dengan permasalahan yang diteliti. (2). Metode riset lapangan, Pendekatan ini dilaksanakan dengan mengadakan observasi, wawancara dan penyebaran kuesioner. Wawancara dilakukan tanya jawab dengan pelaku UKM setempat untuk memperoleh keterangan-keterangan yang terkait dengan penelitian. Adapun kuesioner diberikan kepada responden penelitian. Kuesioner diberikan bobot sesuai dengan skala Likert.

\section{Teknik Analisis Data}

\section{Uji Validitas dan Reliabilitas}

a. Validitas Instrumen

Tahapan analisis data statistik dalam penelitian ini menggunakan software SPSS 20 for Windows. Uji coba secara empirik menggunakan korelasi product moment. Suatu kuesioner dinyatakan valid apabila nilai $r$ yang diperoleh dari hasil perhitungan (rxy) lebih besar daripada nilai rtabel dengan taraf signifikan 5\%.

b. Reliabilitas Instrumen

Reliabilitas menunjukkan sejauh mana suatu pengukuran dapat menghasilkan hasil yang stabil bila dilakukan pengukuran ulang kepada subyek yang sama. Uji reliabilitas menggunakan teknik rumus Alpha Cronbach. Suatu kuesioner dinyatakan reliabel apabila nilai rhitung lebih besar daripada nilai rtabel dengan taraf signifikan 5\%.

\section{Uji Normalitas}

Uji Normalitas digunakan karena pemakaian tehnik analisa korelasi yang akan dipergunakan mensyaratkan dipenuhinya ketentuan data dari variabel yang akan diteliti berdistribusi normal atau mendekati normal. Pengujian Normalitas 
dilakukan dengan menggunakan rumus Chi Kuadrat (X2). Nilai Chi Kuadrat hitung ini dikonsultasikan dengan nilai Chi Kuadrat tabel dengan derajat kebebasan (df) $=k-1$ dan taraf signifikan $a=5 \%$. Distribusi data akan dikatakan normal apabila X2hitung < X2tabel. Hal ini juga berarti nilai-nilai yang diobservasi tidak menyimpang secara signifikan dari frekuensi harapan.

\section{Koefisien Determinasi}

Koefisien determinasi untuk mengukur besarnya persentase dari variabel bebas terhadap variabel terikat dengan menggunakan rumus: $K D=r 2 x$ $100 \%$.

\section{Uji F (Anova)}

Uji $\mathrm{F}$ digunakan untuk mengetahui apakah model mempunyai hubungan linear antara variabel independen terhadap variabel dependen. Adapun kriteria pengujian :

- Ho diterima, jika Fhitung < Ftabel berarti tidak ada hubungan linear antara variabel independen terhadap variabel dependen.

- Ho ditolak, jika Fhitung > Ftabel berarti ada hubungan linear antara variabel independen terhadap variabel dependen.

\section{Analisis Regresi}

Analisis Regresi dengan persamaan berikut ini:

$$
\begin{gathered}
\mathrm{Y}=\mathrm{a}+\mathrm{b} 1 \mathrm{X} 1+\mathrm{b} 2 \mathrm{X} 2 \\
\text { Dimana : } \\
\mathrm{Y} \quad=\text { Keunggulan bersaing } \\
\mathrm{X} 1=\text { Orientasi pasar } \\
\mathrm{X} 2=\text { Inovasi produk } \\
\mathrm{b} 1, \mathrm{~b} 2=\text { Koefisien regresi }
\end{gathered}
$$

\section{Ujit}

Untuk mengetahui pengaruh Orientasi pasar (X1) dan Inovasi produk
(X2) terhadap Keunggulan bersaing (Y) menggunakan uji t (uji parsial), Adapun kriteria uji $t$ antara variabel independen dengan variabel dependen mengunakan keputusan uji sebagai berikut:

- Ho diterima jika $\mathrm{t}$ hitung $<\mathrm{t}$ tabel, artinya tidak ada pengaruh parsial dari masing-masing variabel bebas yaitu Orientasi pasar (X1) atau Inovasi produk (X2) terhadap variabel dependen yakni Keunggulan bersaing (Y)

- Ho ditolak jika, $\mathrm{t}$ hitung $>\mathrm{t}$ tabel, artinya ada pengaruh yang signifikan antara masing-masing variabel bebas Orientasi pasar (X1) atau Inovasi produk (X2) terhadap variabel dependen yakni Keunggulan bersaing (Y)

\section{HASIL PENELITIAN DAN PEMBAHASAN \\ Hasil Penelitian \\ Uji Validitas dan Reliabilitas}

Uji Validitas variabel Orientasi Pasar (X1), Inovasi produk (X2) dan Keunggulan bersaing (Y) menunjukkan bahwa keseluruhan item variabel valid. Demikian pula hasil uji reliabilitas masig-masing variabel penelitian tersebut dinyatakan reliabel.

\section{Uji Normalitas}

Hasil uji normalitas orientasi pasar (X1), diperoleh nilai X2hitung sebesar 16,832 , sedangkan nilai X2tabel pada taraf signifikan $\square=0,05$ dan derajat kebebasan $($ df $)=16$ adalah sebesar 26,294. Dengan demikian X2hitung < dari pada X2tabel. Hal ini berarti frekuensi data untuk orientasi pasar (X1), berdistribusi normal atau tidak menyimpang dari frekuensi yang diharapkan.

Hasil uji normalitas inovasi produk (X2) diperoleh nilai X2hitung sebesar 7,967 
sedangkan nilai X2tabel pada taraf signifikan $\alpha=0,05$ dan derajat kebebasan $(\mathrm{df})=20$ adalah sebesar 31,410. Dengan demikian X2hitung < daripada X2tabel. Hal ini berarti frekuensi skor/data hasil observasi untuk inovasi produk (X2) berdistribusi normal atau tidak menyimpang dari frekuensi yang diharapkan.

Pada uji normalitas keunggulan bersaing (Y), diperoleh nilai X2hitung sebesar 13,756 sedangkan nilai X2tabel pada taraf signifikan $\square=0,05$ dan derajat kebebasan $(\mathrm{df})=15$ adalah sebesar 24,974. Dengan demikian X2hitung < daripada X2tabel. Hal ini berarti frekuensi skor/data hasil observasi untuk keunggulan bersaing (Y) berdistribusi normal atau tidak menyimpang dari frekuensi yang diharapkan.

\section{Koefisien Determinasi Orientasi Pasar dan Inovasi Produk terhadap Keunggulan Bersaing}

Tabel 3

Model Summary

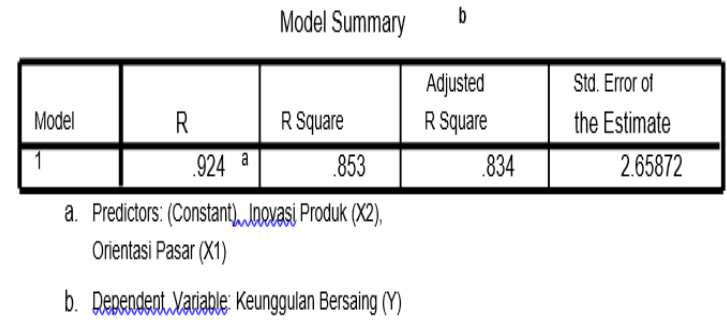

Berdasarkan pada tabel tersebut diatas yakni model summary yang menghasilkan nilai $\mathrm{R}$ sebesar 0,924 dan nilai $\mathrm{R}$ Square sebesar 0,853 atau 85,3\%, yang menunjukkan bahwa secara simultan orientasi pasar (X1) dan inovasi produk (X2) memiliki kontribusi pengaruh terhadap keunggulan bersaing $(\mathrm{Y})$ sebesar $85,3 \%$ sedangkan sisanya $14,7 \%$ dipengaruhi oleh variabel lain yang tidak diteliti.

\section{Uji Anova (Uji F)}

Hasil Uji ANOVA (Uji F) dapat dilihat pada tabel berikut ini.

Tabel 4

Anova

ANOVA b

\begin{tabular}{|c|c|c|c|c|c|c|}
\hline \multicolumn{2}{|c|}{ Model } & $\begin{array}{l}\text { Sum of } \\
\text { Squares }\end{array}$ & df & Mean Square & $F$ & Sig. \\
\hline \multirow[t]{3}{*}{1} & Regression & 1475.235 & 2 & 783.156 & 109.603 & $.000^{\mathrm{a}}$ \\
\hline & Residual & 215.284 & 32 & 7.074 & & \\
\hline & Total & 1690.519 & 34 & & & \\
\hline
\end{tabular}

Berdasarkan table diatas, terlihat bahwa dari hasil uji ANOVA (Analysis of Variance) atau Ftest dalam penelitian ini berupa Univariate Two Way Analysis of Variance karena variabel bebas ada 2, sedangkan variabel terikat ada satu. Uji ANOVA diperoleh nilai sebesar 109.603 dimana lebih besar dari Ftabel (34) sebesar 2,880 dengan tingkat signifikan sebesar 0,000 .

Hal ini menunjukkan bahwa penekanan pada strategi yang tertuju pada esensi orientasi pasar maupun ragam inovasi produk (barang dan jasa) yang dilakukan oleh masing-masing entitas restoran/kafe yang dijalankan selama ini harus dipertahankan, bila perlu ditingkatkan secara berkesinambungan untuk mewujudkan dan mencapai pengguatan keunggulan bersaing.

\section{Analisis Regresi}

Hasil analisis regresi dapat dilihat pada tabel berikut ini:

Tabel 5

Analisis Regresi

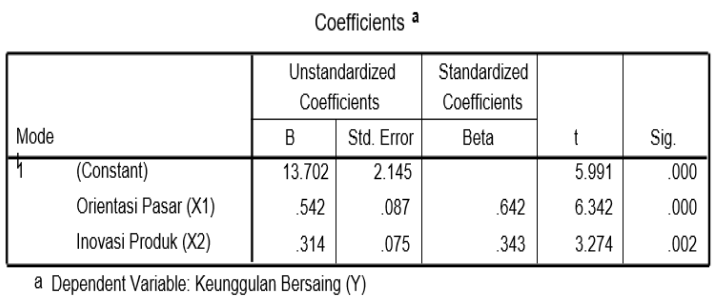


Berdasarkan tabel diatas, dapat diketahui persamaan regresinya $Y=13,702$ $+0,542 \times 1+0,314 \times 2$ yang dapat dijelaskan sebagai berikut :

a. Nilai koefisen regresi orientasi pasar (X1) terhadap keunggulan bersaing $(Y)$ adalah sebesar 0,542 atau bernilai positif.

b. Nilai koefisien regresi variabel inovasi produk (X2) terhadap (Y) adalah sebesar 0,314 atau bernilai positif.

\section{Uji $t$ (Uji Hipotesis Pengaruh secara Parsial)}

Untuk mengetahui apakah masingmasing orientasi pasar (X1) dan variabel inovasi produk (X2) secara parsial mempunyai pengaruh yang signifikan terhadap keunggulan bersaing (Y) dilakukan pengujian $t$ dengan cara membandingkan antara hasil thitung dengan ttabel.

Tabel 6

Hasil Uji t

\begin{tabular}{|l|c|c|c|c|}
\hline \multicolumn{1}{|c|}{ Variabel } & Nilai & $\begin{array}{c}\text { Standard } \\
\text { Error }\end{array}$ & thitung & tabel \\
\hline $\begin{array}{l}\text { Orientasi pasar } \\
\left(\mathrm{X}_{1}\right)\end{array}$ & 0,542 & 0,087 & 6.342 & 1,696 \\
\hline $\begin{array}{l}\text { Inovasi produk } \\
\left(\mathrm{X}_{2}\right)\end{array}$ & 0,314 & 0,075 & 3.274 & 1,696 \\
\hline
\end{tabular}

Berdasarkan hasil uji t tersebut di atas, terbukti bahwa secara signifikan orientasi pasar (X1) mempunyai pengaruh positif terhadap keunggulan bersaing $(\mathrm{Y})$ dimana nilai thitung lebih besar dari tTabel, sedangkan inovasi produk (X2) juga mempunyai pengaruh positif terhadap keunggulan bersaing (Y), dimana nilai thitung lebih besar dari ttabel,. Dengan demikian orientasi pasar (X1) dan inovasi produk (X2) secara signifikan mempunyai pengaruh terhadap keunggulan bersaing (Y).

\section{PEMBAHASAN}

Penelitian ini menemukan model bahwa orientasi pasar (X1) dan inovasi produk (X2) memiliki kontribusi pengaruh terhadap keunggulan bersaing $(Y)$ sebesar $85,3 \%$. Adapun temuan model persamaan regresi linear ganda dalam penelitian ini adalah $\mathrm{Y}=13,702+0,542 \mathrm{X} 1+0,314 \mathrm{X} 2$.

\section{Pengaruh orientasi pasar terhadap keunggulan bersaing}

Nilai koefisien regresi orientasi pasar yaitu b1 sebesar 0,542 pada model persamaan regresi linear berganda menunjukkan bahwa orientasi pasar mempunyai pengaruh pada arah yang positif, artinya semakin tinggi kebijakan yang berorientasi pasar, maka akan berpengaruh pada semakin tingginya keunggulan bersaing.

Hasil penelitian sejalan dengan penelitian Talaja, et al., (2017) yang menemukan bahwa orientasi pasar berpengaruh positif secara signifikan terhadap keunggulan bersaing. Penelitian ini juga sejalan dengan penelitian oleh Dalimunthe (2017) yang menemukan bahwa terdapat pengaruh langsung dan positif secara signifikan antara orientasi pasar terhadap keunggulan bersaing.

Temuan penelitian ini menunjukkan bahwa variabel orientasi pasar, dimana dalam penelitian ini lebih ditekankan pada value utama perusahaan, segmentasi pasar, pemenuhan kebutuhan, keinginan pelanggan, orientasi pelanggan dan pesaing serta koordinasi lintas fungsi memberikan pengaruh positif terhadap keunggulan bersaing.

\section{Pengaruh inovasi produk terhadap keunggulan bersaing \\ Nilai koefisien regresi inovasi produk} yaitu b2 sebesar 0,314 pada model persamaan regresi linear berganda menunjukkan bahwa inovasi produk mempunyai pengaruh pada arah yang positif, artinya semakin tinggi kebijakan inovasi produk, maka akan berpengaruh 
pada semakin tingginya keunggulan bersaing.

Hasil penelitian ini sejalan dengan penelitian Djodjobo dan Tawas (2014) yang menemukan bahwa inovasi produk berpengaruh positif dan signifikan terhadap keunggulan bersaing. Demikian pula dengan penelitian Chen dan Chang (2013) yang secara khusus meneliti inovasi produk berbasis green product inovation yang menemukan adanya pengaruh positif dan signifikan inovasi produk terhadap keunggulan bersaing perusahaan. Hasil penelitian ini juga sejalan dengan penelitian Dalimunthe (2017) juga menyimpulkan bahwa terdapat pengaruh langsung dan positif secara signifikan antara inovasi produk terhadap keunggulan bersaing.

Temuan penelitian ini menunjukkan bahwa variabel Inovasi produk, dimana dalam penelitian ini lebih ditekankan pada pengembangan desain produk, desain kekhasan merek, Kekhasan produk, Mengelola Produk dan Keanekaragaman produk memberikan pengaruh positif terhadap keunggulan bersaing.

\section{KESIMPULAN}

1. Orientasi pasar berpengaruh positif terhadap variabel keunggulan bersaing; semakin tinggi orientasi pasar maka semakin tinggi pula keunggulan bersaing.

2. Inovasi produk berpengaruh positif terhadap variabel keunggulan bersaing; semakin tinggi inovasi produk maka semakin tinggi pula keunggulan bersaing.

\section{SARAN}

1. Pelaku usaha UKM di lokasi penelitian sangat perlu untuk memprioritaskan strategi yang berorientasi pasar termasuk trend kebutuhan, keinginan dan ekpektasi dari konsumen, kemitraan dengan supplier serta scanning terhadap kompetitor. Demikian juga perhatian dalam melakukan inovasi produk yang memberikan nilai tambah (added value) sekaligus solusi bagi pelanggan.

2. Keunggulan bersaing (competitive advantages) telah menjadi keniscayaan agar bisa survive di tengah dinamika kompetisi bisnis kuliner dan perkembangan pasar, termasuk kebutuhan, keinginan dan ekspektasi konsumen serta strategi dari kompetitor (lama maupun pemain baru) yang relatif cepat. Hal ini idealnya selalu menjadi perhatian pelaku usaha sektor UKM bisnis kuliner agar tetap eksis dan berkembang.

3. Mengingat keterbatasan penelitian ini dari segi variabel penelitian dan indikator dari variabel serta cakupan sampel penelitian, diharapkan pada pengembangan penelitian selanjutnya bisa dilakukan dengan penguatan pada beberapa aspek tersebut.

\section{DAFTAR PUSTAKA}

Andrew, J., J. Manget, D. Michael, A. Taylor, and H. Zablit. 2010. Innovation 2010. BCG Report.

Barney,J.B. 2010. Gaining and Sustaining Competitive Advantage, Fourth Edition. Addison-Wesley, Massachusetts.

Chen Y.S., Chang K.C, 2013, The nonlinear effect of green innovation on the corporate competitive advantage, Qual Quant (2013) 47:271-286, DOI 10.1007/s $11135-01$ 1-9518-x

Crawford, C. Merle; Di Benedetto, C. Anthony. 2000. New Products 
Management, Sixth Edition. McGraw-Hill, New York.

Dalimunthe, M, B, 2017, Keunggulan Bersaing Melalui Orientasi Pasar dan Inovasi Produk, Jurnal Konsep Bisnis dan Manajemen, Vol 3 No. 1, hal 18-31

Damanpour, F. 1991. Organizational Innovation: A Meta Analysis of Effect of Determinants and Moderators. Academy of Management Journal, 34(3): 555590.

Djodjobo, Cynthia. V, dan Tawas H.N., 2014, Pengaruh Orientasi Kewirausahaan, Inovasi Produk dan Keunggulan Bersaing terhadap Kinerja Pemasaran Usaha Nasi Kuning di Kota Manado, Jurnal EMBA, Vol.2 No.3 September 2014, Hal. 1214-1224

Han, Jin K, Narnwoon Kim, and Rajenbdra K Srivastava, 1998, Market Orientation an Organization Performance: Is Innovation Missing Link?, Journal of Marketing, p. 42 - 54

Homburg C, Pflesser CA. Multiple-layer model of market-oriented organizational culture: measurement issues and performance outcomes. Journal of Marketing Research, 2000; 37 (4):449-62

Kotler, P., Armstrong, G., Ang,G.H., Leong, S.M., Tan, C.T., dan Tse, D.K. 2005. Principles of Marketing: An Asian Perspective. Pearson Prentice Hall, Singapore.

Kumar, V., Jones, E., Venkatesan, R., \& Leone, R. P. (2011). Is Market Orientation a Source of Sustainable Competitive Advantage or Simply the Cost of Competing? Journal of Marketing, 75(1), 16-30.
Kuncoro, Mudrajad. 2003. Metode Riset Untuk Bisnis dan Ekonomi. Jakarta : Erlangga

McDaniel, B.A. 2002, Entrepreneurship and Innovation: An Economic Approach. M.E.Sharpe,Inc, New York.

Meehan SA. What do We Really Know About Market Orientation? Business Strategy Rev 1996;7(1):47-53.

Morissan. 2014. Metode Penelitian Survei. Kencana, Jakarta,

Narver, J. C., and Slater, S. F., 1995, Market Orientation and The Learning Organization, Journal of Marketing. p.63- 74 .

Porter, Michael E. 2008, Competitive Advantage (Keunggulan Bersaing). Tangerang, Karisma Publishing Group.

Sekaran U, Roger Bougie, 2013, Research Method for Business, a Skill Building Approach, 6th Edition, John Wiley \& Sons Ltd, UK

Talaja, Anita; Miočević, Dario; Alfirević, Nikša; Pavičić, Jurica., 2017, Market Orientation, Competitive Advantage And Business Performance: Exploring The Indirect Effects, Drustvena Istrazivanja; Zagreb Vol. 26, Iss. 4, p. 583-604.

Urbancova, H., 2013, Competitive Advantage Achievement through Innovation and Knowledge, Journal of Competitiveness, ISSN 1804-171X, Vol.5, No.1. p.82-96.

Wedel M, Kamakura WA. Market Segmentation: Conceptual and Methodological Foundations. 2nd ed. Norwell: Kluwer Academic Publishers; 2002 